\title{
DISTRIBUTION, TAXONOMY AND MEDICINAL IMPORTANCE OF AJUGA BRACTEOSA AND AJUGA PARVIFLORA : A COMPARATIVE STUDY
}

\author{
Shabana Gulzar'1, Afrozah Hassan ${ }^{1}$, Irshad A. Nawchoo' \\ ${ }^{1}$ Plant Reproductive Biology, Genetic Diversity and Phytochemistry Research Laboratory, \\ Department of Botany, University of Kashmir, Srinagar, Jammu and Kashmir. \\ Corresponding author: malikaafreen6@gmail.com
}

\begin{abstract}
:
The Kashmir Himalaya forms a part of the Great Himalayan Range located on the north- west of India, the state of Jammu and Kashmir lies between $32^{\circ} 17^{\prime}$ to $36^{\circ} 26^{\prime} \mathrm{N}$ latitude and $73^{\circ} 26^{\prime}$ to $80^{\circ} 30^{\prime}$ E longitude. Kashmir Himalaya is rich in diversity of medicinal plants. The medicinal plants are used for the treatment of different diseases. However due to the anthropogenic pressure the diversity of medicinal plants is decreased. The genus Ajuga L. is distributed in subtropical and temperate regions from Kashmir to Bhutan, Pakistan, Afghanistan, China, Malaysia, Western Himalayas, plains of Punjab and Upper Gangetic plains of India. It has worldwide distribution growing under wide variety of soil and climate, but more abundant in Mediterranean regions and in the hills. The present review of literature gives an overview of literature regarding the distribution, taxonomic description and medicinal importance of: Ajuga bracteosa Wall. ex Benth. and Ajuga parviflora Benth.
\end{abstract}

Key words: - Ajuga, taxonomy, morphology, ethnomedicinal importance

\section{INTRODUCTION:}

Lamiaceae is the seventh largest family of the order Lamiales with cosmopolitan distribution (Heywood et al., 2007; Yuan et al., 2010). It comprising around 236 genera (Harley et al., 2004) and 6900 (Heywood et al., 2007) to 7200 species (Harley et al., 2004) worldwide. Coll and Tandron (2008) reported that the family comprises of about 220 genera and almost 4000 species. The large number of plants in this family reflects the intensification of taxonomic and ethno-botanical research in this area (Merritt and Ley, 1992). Most plants of Lamiaceae are native to Europe, Asia, and Africa, but also growing in Australia and North America (Flora of China, 1994; Coll and Tendron, 2008). About 60 genera with 980 species occur in Sub-Saharan African region (Klopper et al., 2006).

\section{Geographic Distribution}

The genus Ajuga L. is distributed in subtropical and temperate regions from Kashmir to Bhutan, Pakistan, Afghanistan, China, Malaysia, Western Himalayas, plains of Punjab and Upper Gangetic plains of India (Khare, 2007) at an altitude of $1300 m$. In India, it abounds in Western Himalaya at an altitude of 1300m (Chandel and Bagai, 2010). It is found along roadsides, open slopes, and rock cervices up to $1500 \mathrm{~m}$ above mean sea level (Upadhyay et al., 2011). Most of the plants belonging to genus Ajuga are native to Europe, Asia, and Africa, but also growing in Australia and North America (Flora of China, 1994). It has worldwide distribution growing under wide variety of soil and climate, but more abundant in Mediterranean regions and in the hills.

The genus Ajuga L. consists of about 40-50 species mostly distributed in the north 
temperate zone of the World (Ali and Nasir, 1990) from Europe to Asia and Australia (Keng, 1969). The genus consists of about 301 species (Upadhyay et al., 2011). It is mostly distributed in the north temperate zone of the old world. It also occurs in South Africa and Australia. In flora of Turkey, the genus Ajuga is represented by 14 species and 27 subspecific taxa (Baytop, 1999).

In Kashmir Himalaya only three species of genus Ajuga have been reported which include Ajuga bracteosa Wall. ex Benth., Ajuga parviflora Benth. and Ajuga remota Wall. ex Benth ( Stewart, 1972). A. bracteosa is distributed in sub-tropical and temperate regions from Kashmir to Bhutan, Pakistan, Afghanistan, China and Malaysia. In Pakistan it is found in northern hilly areas, where it is called as Kori booti (meaning, bitter herb) owing to its bitter taste (Pal et al., 2011). It is found on grassy slopes of Afghanistan, India, Myanmar and Nepal (e-flora of China). In India, $A$. bracteosa has been reported from Maharashtra, Tamil Nadu, Kerala, Karnataka, West Bengal (Bandyopadhya et al., 2003) and Himachal Pradesh (Sharma and Mishra, 2009).

A. parviflora Benth has been found to grow in the temperate Kumaon region of the Indian Himalaya at $1200 \mathrm{~m}$ to $1800 \mathrm{~m}$ elevations (Beauchamp et al., 1996). Nawaz et al., (2000) have reported $A$. parviflora in the hilly regions of northern Pakistan. It is an annual or short lived perennial herb that grows in temperate region, widely distributed in east Afghanistan, Himalaya, Kashmir and Pakistan; it flowers between March and October (Rahman et al., 2013). It is a small herb, which grows wild in the temperate regions of Himalaya (Joshi et al., 2014).

\section{Taxonomy and Morphology}

The term Labiatae was coined by De Jussieu in 1789, which originates from the Latin word Labium (lip), referring to the billiped corolla, a salient feature of the family. Lindley proposed the name "Lamiaceae" after the genus Lamium. The International Code of Botanical Nomenclature (ICBN) in 1935 also approved the name Lamiaceae as an alternative name to Labiatae. The family has traditionally been considered closely related to Verbenaceae and in the last revision of the family published in 2004 in which 236 genera were described and provided with keys (Harley et al., 2004).

Lamiaceae has been divided into seven subfamilies with ten genera not placed in any of the subfamilies. The unplaced genera included: Tectona, Callicarpa, Hymenopyramis, Petraeovitex, Peronema, Garrettia, Cymaria, Acrymia, Holocheila, and Ombrocharis. The subfamilies are Symphorematoideae, Viticoideae, Ajugoideae, Prostantheroideae, Nepetoideae, Scutellariodeae, and Lamioideae. The subfamily Vitcodeae is probably not monophyletic and Prostantheroideae and Nepetoideae are divided into tribes (Harley et al., 2004; Gemma et al., 2009).

The generic name Ajuga derives from the Greek meaning without a yoke in reference to a yoke-yellow to the lower lip of the corolla (Fernald, 1950). The plants belonging to this genus are evergreen, clump-forming rhizomatous annual or perennial herbaceous flowering species. It can be distinguished from other genera of Lamiaceae by the combination of reticulately sculptured mericarps, which separate late in development producing a prominent areole at the point of attachment, and a persistent corolla base, which often leaves a sheath around the mature mericarps (Harley et al., 2004). According to Isriaili and Lyossi (2009) the Ajuga plants grow upto 5$50 \mathrm{~cm}$ tall, with opposite leaves. The flowers are two lipped and tubular, mostly blue, purple or yellow in colour.

Ajuga bracteosa is perennial, erect or ascending hairy herb, often prostrate with 
oblanceolate or sub-spathulate leaves. Stems are branched from base, $10-30 \mathrm{~cm}$ tall, gray villous or lanate-villous especially on young parts. Basal petioles $1-1.5 \mathrm{~cm}$; basal leaf blade spatulate to oblanceolate, stem blades sessile or subsessile, obovate to subcircular, pilose or strigose, base cuneate-decurrent, margin inconspicuously to irregularly undulatecrenate, ciliate, apex obtuse to subrounded. Basal verticillasters widely spaced, apical verticillasters in dense spikes; basal floral leaves densely lanate-villous, incised, ciliate. Calyx campanulate, villous especially on teeth; teeth subulate- triangular, regular, $1 / 2$ or more as long as calyx, apically acute, margin villous-ciliate. Corolla purple or purplish with dark purple spots, tubular, slightly exserted, puberulent, yellowish glandular, villous annulate inside; upper lip straight, apex emarginate; middle lobe of lower lip obcordate, lateral lobes oblong. Nutlets oblong to oblongobovoid, adaxially swollen at middle, areole to $2 / 3$ or more as long as adaxial side of nutlet (flora of china). Flowers are white or purplishviolet tinged from lower surface in distant, axillary whorls in spike .It usually flowers between March to December (Pal et al., 2011).

Ajuga parviflora is an annual or short lived perennial herb (Nawaz et al., 1999). It is an annual or short-lived perennial herb with stems spreading or ascending, $10-25 \mathrm{~cm}$, usually unbranched, with a sparse to dense glandular indumentum of long villous multicellular hairs. Leaves may be rosetteforming, variable in size, up to $45 \times 25 \mathrm{~mm}$, obovate-spathulate to elliptic, entire to crenate, narrowed into petiole, entire to irregularly crenate, with multicellular glandular hairs, thin-textured; petiole on basal leaves up to $20 \mathrm{~mm}$; cauline leaves smaller than basal and decreasing up the stem. Inflorescence unbranched of up to 18 distant or approximating 8-12-flowered verticillasters. It usually flowers between March-June. A. parviflora is unusually densely villous in comparison with other species (www eflora of china).

\section{RESULT AND DISCUSSION:}

Medicinal plants have been used for centuries in traditional health care systems and thus contribute significantly to human health. With the recent advancements in plant sciences, there has been a tremendous increase in the use of plant based health products in developing as well as developed countries. However India is not able to keep pace with other nations having equally rich biodiversity and traditional knowledge systems. This is evident by a planning commission report, which has projected that India has less than $2 \%$ global herbal market, whereas China with similar biodiversity and ecological conditions has $25 \%$ share. The cause for this has been identified as the lack of scientific data on Indian herbs (Tripathi et al., 2009). Hence, India needs to augment its research in herbal medicine by encouraging the scientific force at both research and educational institutions. Due to the immense medicinal importance, Ajuga bracteosa and Ajuga parviflora are extracted by the locals for various ethnomedicinal uses which leads to decline of Ajuga bracteosa hence the species became critically endangered (Ahmad et al., 2012). The present review is an attempt to highlight the importance of two medicinal plants growing in Kashmir Himalaya. It is very common among the people who live in upper reaches of Kashmir Himalaya to use herbs for curing of various diseases (Dutt et al., 2015).

\section{Acknowledgement}

We are highly thankful to department of Botany University of Kashmir for providing necessary facilities 
Ahmad, K.S., Kayani, W.K., Hameed , M., Ahmad, F., Nawaz. T. 2012. Floristic diversity and ethnobotany of senhsa, district Kotli, Azad Jammu \& Kashmir

(Pakistan). Pak J Bot 2012; 44: 195-201.

Ali S I, Nasir YJ. 1990. Flora of Pakistan, $\mathrm{BCC}$ and $\mathrm{T}$ Press, University of Karachi, Vol. 192, 14.

Beauchamp, P.S., Bottini, A.T., Caselles, M. C., Dev, V., H. Hope, M. Larter, G. Lee, C.S. Mathela, A.B. Melkani, P.D. Millar, M. Miyatake, A.K. Pant, J. Raffel, V.K. Sharma and D. Wyatt. 1996. Neo-clerodane diterpenoids from Ajuga parviflora. Phytochemistry, 43, 827.

Chandel, S., Bagai U. 2011. Screening of antiplasmodial efficacy of Ajuga bracteosa Wall ex. Benth. Parasitol Res. 108: 801-5.

Coll, J. and Tandron, Y. A. 2008. Neoclerodane diterpenoids from Ajuga: structural elucidation and biological activity. Phytochem. Rev. 7: 25- 49

Dutt, H. C., Bhagat, N.and Pandita, S. (2015). Oral traditional knowledge on medicinal plants in jeopardy among Gaddi shepherds in hills of northwestern Himalaya, J\&K, India. Journal of ethnopharmacology.168: 337-348.

Fernald, M.L. 1950. Ajuga in Gray's Manual Botany. American Book Co., New York.
Flora. 1994. Flora of China, 17: 63-69 http: //www. efloras.org.

Gemma, L.C., Bramley, Forest, F. and de Kok, R.P.J. 2009. Troublesome tropical mints: re-examining generic limits of Vitex and relations (Lamiaceae) in South East Asia. Taxon, 58(2): 500-510.

Gokhle., Karandikar., Patel. 1962. Positive inotropic action of an alkaloid fraction from Ajuga bracteosa Wall. ex Benth. Indian $J$ Physiol Pharmacol, 6: 224.

Hussain, M., Yamin, B., Naveed, I. R., Muhammad, I., Sumaira, A., Nida, T., ... \& Anam, I. (2016). A review of therapeutic potential of Ajuga bracteosa: A critically endangered plant from Himalaya. Journal of Coastal Life and Medicine, 4, 918924.

Harley, R. M., Atkins, S., Budantsev, A., Cantino, P. D., Conn, B.J., Grayer, R. J., Harley, M. M., de Kok, R. P. J., Krestovskaja, T. V., Morales, R., Paton, A. J. and Ryding, P. O. 2004. Labiatae. In: Kubitzki, K. and Kadereit, J. W. (Eds), The families and Genera of Vascular Plants.Springer- Verlag, Berlin, Heidelberg, Germany, 7 : 167- 275

Heywood, V. H., Brummitt, R. K., Seberg, O. and Culham, A. 2007. Flowering Plant Families of the World. Firefly Books, Ontario, Canada. 
Israili, Z. H. and Lyoussi, B. 2009. Ethnopharmacology of the plants of genus Ajuga. Pak. J. Pharm. Sci. 22(4): 425-462.

Joshi, R.K., Joshi, B.C. and Sati, M. K. 2014. Chemical and Chemotaxonomic Aspects of Some Aromatic and Medicinal Plants Species from Utrrakhand: A Review: Asian J. Pharm. Tech., 4(3): 157-162

Kaul, M. K. 1997. Medicinal plants of Kashmir and ladakh, Temperate and Cold Arid Himalaya (Indus Publishing, New Delhi) 87.

Keng, H. 1969. Flora Malesiana Precursores XLVII. A revision of Malesian Labiatae. Gard. Bull. Straits Settlem. 26: 13-180

Klopper, R. R., Chatelain, C., Banninger, V., Habashi, C., Steyn, H. M., De Wet, B. C., Arnold, T. H., Gautier, L., Smith, G. F. and Spichiger, R. 2006. Checklist of the flowering plants of Sub- Saharan Africa. An index of accepted names and synonyms. Southern African Botanical Diversity Network Report No. 42. SABONET, Pretoria.

Linnaeus, C. 1753. Species plantarum [1st edition] 2 vols. Holmiae: Salvius. Reprint, Anon. 1957. Carl Linnaeus. A. Facsimile of the first edition 1753 2 vols. London: Ray Society.

Merritt, A. T. and Ley, S. V. 1992. Clerodane diterpenoids. Nat. Prod. Rep. 9: 243.
Nawaz, H.R., Malik, A., Khan, P.M. and Ahmed, S. 1999. Ajugin E and F: two withanolides from Ajuga parviflora. Phytochemistry, 52: 1357-1360.

Nawaz, H. R., Malik, A., Muhammad, P., Ahmed, S. and Riaz, M. 2000. Chemical constituents of Ajuga parviflora. Z. Naturforsch., 55: 100103.

Pal, A., Jadon, M., Katare, Y.K., Singour, P.K., Rajak,H., Chaurasiya, P.K., Patil, U.K. and Pawar, R.S 2011. Ajuga bracteosa wall: A review on its ethnopharmacological and phytochemical studies Der Pharmacia Sinica, 2 (2): 1-10

Rahman, N., Ahmad, M., Riaz, M., Mehjabeen, Noor Jahan, N. and Ahmad, R. 2013. Phytochemical, antimicrobial, insecticidal and brine shrimp lethality bioassay of the crude methanolic extract of Ajuga parviflora Benth. Pak. J. Pharm. Sci., Vol. 26, No.4

Sharma, P. and Mishra, N. K. 2009. Diversity, utilization pattern and indigenous uses of plants in an around a cement factory in Bilaspur District of Himachal Pradesh, North Western Himalaya. An International Journal, 1: 89-91.

Shen, X., Isogai, A., Furihata, K., Sun, H. and Suzuki, A. 1993. Two neo clerodane diterpenoids from Ajuga 
macrosperma. Phytochemistry,

33: 887-889.

Stewart, R. R. 1972. Flora of West Pakistan: an annotated catalogue of the vascular plants of West Pakistan and Kashmir. Rawalpindi) $\mathrm{xx}$, 1028p. Map Geog, 6.

Upadhyay, S.U., Patel, V.B., Patel, A. A., Upadhyay, U.L., Patel, N.M. 2011. Ajuga bracteosa- A promising herb.

$\begin{array}{lll}\text { Pharma Science } & \text { Monitor - An } \\ \text { International } & \text { Journal } & \text { of }\end{array}$

Pharmaceutical Sciences, 2080-88.

Yuan, Y., Mabberly, D. J., Steane, D. A. and Olmstead, R. J. 2010. Further disintegration and redefinition of Clerodendrum (Lamiaceae): Implications for the understanding of the evolution of an intriguing breeding strategy. Taxon. 59 (1): 125- 133

Table 2.1: Different species of Ajuga from China (Linnaeus, 1753)

\begin{tabular}{|c|c|}
\hline $\begin{array}{l}\text { S. } \\
\text { No. }\end{array}$ & Name of the species \\
\hline 1. & Ajuga lobata \\
\hline 2. & Ajuga pygmaea \\
\hline 3. & Ajuga sciaphila \\
\hline 4. & Ajuga nubigena \\
\hline 5. & Ajuga lupulina \\
\hline 6. & Ajuga ovalifolia \\
\hline 7. & Ajuga ciliate \\
\hline 8. & Ajuga multiflora \\
\hline 9. & Ajuga campylanthoides \\
\hline 10. & Ajuga campylantha \\
\hline 11. & Ajuga forrestii \\
\hline 12. & Ajuga bracteosa \\
\hline 13. & Ajuga pantantha \\
\hline 14. & Ajuga decumbens \\
\hline 15. & Ajuga nipponensis \\
\hline 16. & Ajuga dictyocarpa \\
\hline 17. & Ajuga macrosperma \\
\hline 18. & \\
\hline
\end{tabular}




\section{Ajuga linearifolia}

Table 2.2: Traditional methods of applications of A. bracteosa (Hussain et al., 2016).

\begin{tabular}{|c|c|}
\hline Disease & Methods of applications \\
\hline Headache & Paste of the leaves is applied to cure headache. \\
\hline Abdominal pain & $\begin{array}{l}\text { Powder of the whole plant is given to treat } \\
\text { abdominal pain. }\end{array}$ \\
\hline Indigestion & $\begin{array}{l}\text { Powder of whole plant is also used to treat } \\
\text { indigestion. }\end{array}$ \\
\hline Astringent & Whole plant is used as astringent. \\
\hline Tonic & Whole plant is also used as tonic. \\
\hline Internal colic & Whole plant is used to treat internal colic. \\
\hline Pimples & Barks juice is used to treat pimples. \\
\hline Jaundice & Leaves extracts are used to treat jaundice. \\
\hline Hypertension & Whole plant is used to treat hypertension. \\
\hline Sore throat & Whole plant is used to sore throat. \\
\hline Cold & Decoction of root is taken. \\
\hline Leprosy & Root powder is ingested. \\
\hline Blood purification & Leaves extract is used for blood purification. \\
\hline Diabetes & $\begin{array}{l}\text { Decoction of leaves is used to treat the } \\
\text { diabetes. }\end{array}$ \\
\hline Fever & Decoction of leaves is used to treat the fever. \\
\hline Swollen wounds & $\begin{array}{l}\text { Plant extract is used is used to cure swollen } \\
\text { wounds. }\end{array}$ \\
\hline Bites of insects & $\begin{array}{l}\text { Plant extract is used is used to cure bites of } \\
\text { insects. }\end{array}$ \\
\hline Eye trouble & Plant extract is used is used to cure eye trouble. \\
\hline Bladder disease & $\begin{array}{l}\text { Plant extract is used is used to treat bladder } \\
\text { disease. }\end{array}$ \\
\hline
\end{tabular}

